Jurnal Manajemen Indonesia Vol. 21(2), pp. 153 - 160, 2021)

Online ISSN : 2502-3713 | Print ISSN : 1411-7835

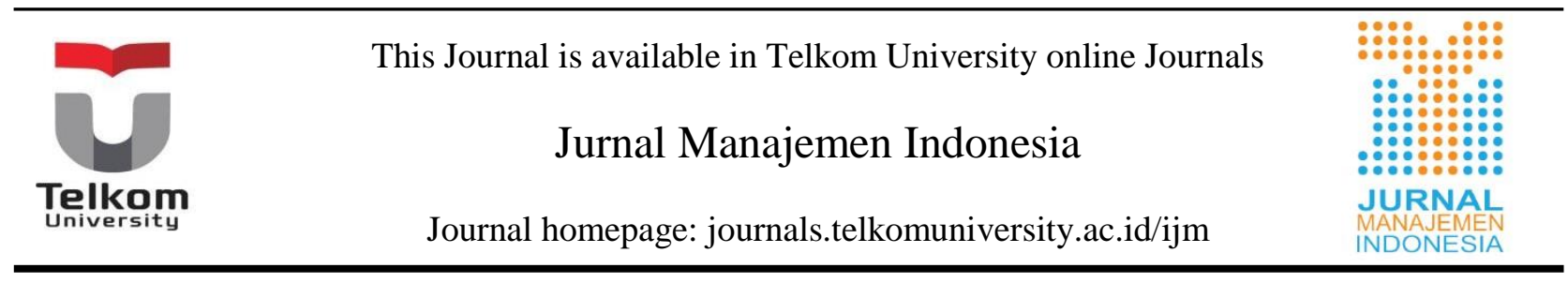

\title{
Market Efficiency of Exchange Rate of Bitcoin with Dollar and Rupiah of Foreign Exchange Markets: Weak and Semi-Strong Form Test
}

\author{
Rizal Nora Amelda ${ }^{1}$, Umardi Valenchya Kristina ${ }^{2}$ \\ ${ }^{1,2}$ Faculty of Economics and Business, TelkomUniversity, Bandung, Indonesia
}

\begin{abstract}
Bitcoin is one of the cryptocurrencies that had a high rate of return since its appearance in 2009. However, the exchange rate of Bitcoin against any foreign currency is considered to have high volatility making it difficult to determine the real value of Bitcoin. The main purpose of this research is to find the value of Bitcoin, especially US Dollar and Rupiah currencies. The test is carried out using the weak market efficiency hypothesis and the semi-form market coefficient hypothesis. The data processing methods are used the stationary test (ADF, KPSS, and ERS) to test the efficiency of the weak form market and the cointegration test (Johansen Cointegration) with the VECM model to check the efficiency of the semi-strong market. The results show that the Bitcoin exchange rate does not have a unit root so it is inefficient in a weak form and has a negative effect on the USD / IDR exchange rate so that it is not efficient in semi-strong form as well as on the US Dollar and Rupiah exchange rates. This happens because Bitcoin transactions as a medium of exchange in Indonesia are still illegal. So that the Bitcoin exchange rate against the US Dollar and Rupiah exchange rates is biased because it does not reflect the available information, both historical information and public information.
\end{abstract}

Keywords-Bitcoin Exchange Rate; Market Efficiency; Unit Root; Cointegration

\begin{abstract}
Abstrak
Bitcoin merupakan salah satu mata uang crypto yang memiliki tingkat return yang tinggi semenjak kemunculannya pada 2009. Namun, nilai tukar bitcoin terhadap setiap mata uang asing dianggap memiliki volatilitas yang tinggi sehingga sulit untuk menentukan nilai riil dari Bitcoin. Tujuan utama dari penelitian ini adalah untuk menemukan nilai rill dari Bitcoin khususnya terhadap mata uang Dolar Amerika dan Rupiah. Pengujian dilakukan dengan menggunakan hipotesis efisiensi pasar bentuk lemah dan hipotesis efisiensi pasar bentuk semi-kuat. Metode pengolahan data yang digunakan yaitu Uji stasioner (ADF, KPSS, dan ERS) untuk menguji efisiensi pasar bentuk lemah dan Uji Kointegrasi (Johansen Cointegration) dengan model VECM untuk menguji efisiensi pasar bentuk semi-kuat. Hasil penelitian menunjukkan bahwa nilai tukar Bitcoin tidak memiliki akar unit sehingga tidak efisien dalam bentuk lemah dan memilik pengaruh negatif terhadap nilai tukar USD/IDR sehingga tidak efisien dalam bentuk semi-kuat juga terhadap nilai tukar Dollar Amerika dan Rupiah. Hal ini dikarenakan transaksi Bitcoin sebagai alat tukar di Indonesia masih illegal. Sehingga nilai tukar Bitcoin terhadap nilai tukar Dolar Amerika dan Rupiah bias karena belum mencerminkan informasi yang tersedia baik informasi historikal maupun informasi publik.
\end{abstract}

Kata kunci- Nilai Tukar Bitcoin; Efisiensi Pasar; Akar Unit; kointegrasi 


\section{INTRODUCTION}

Since it was first conceived by Satoshi Nakamoto in 2008, cryptocurrencies have attracted significant investor attention. Cryptocurrency is electronic money that uses a peer-to-peer system that allows online payments to be sent directly without going through a financial institution. Currently the most well-known cryptocurrency on the market is Bitcoin. Bitcoin is the first decentralized digital currency designed by Nakamoto in 2009. Bitcoin transactions are carried out almost all over the world and in many countries with different currencies every day (Nan and Kaizoji, 2019). In some markets, they provide multi- currency bitcoin trading services which allow bitcoin to develop into a new form of foreign markets. Therefore, the exchange rate of bitcoin against foreign currency exchange rates is needed to facilitate the transaction process. According to Wijaya (2019) the bitcoin exchange rate is more stable than the foreign currency exchange rate because the value of bitcoin tends to be only influenced by the amount of market demand and supply and is not influenced by the political conditions of a particular country. This is causes many researcher are interested to knowing the exchange rate of bitcoin against a foreign currency. Therefore, the researcher also wants to conduct research on the exchange rate of bitcoin against the US Dollar and Rupiah.

In an efficient market, prices will immediately respond to new information, while future prices are unpredictable and have random changes because events that occur in the future are also unpredictable. Therefore, prices follow the nature of a random walk which is in accordance with Fama's (1970) theory that market efficiency is based on the idea that the price formed is fully reflected in the information available. Much research has been conducted to determine the market efficiency of bitcoin, but most of them only analyze using weak form market hypotheses. As time goes by and the market grows, the efficiency level of bitcoin is increasing. This led researchers to add the market efficiency hypothesis to a semi-strong form for testing the bitcoin market. Therefore, to find the semi-strong efficiency level of Bitcoin and USD / IDR, the researcher used the cointegration method.

Cointegration became the subject of research after Engle \& Granger (1987) introduced the concept. Cointegration is a condition that occurs when the independent variable and dependent variable are time series data and are not stationary (Winarno, 2017: 111). The purpose of the cointegration test is to see the long-term relationship between variables. According to Basuki and Prawoto (2017: 253) if there is cointegration in the variables used, then there is also a long-term relationship between these variables.

\section{LITERATURE REVIEW}

The first is based on research conducted by Urquhart (2016) entitled The Inefiiciency of Bitcoin, which is the first research on the market efficiency of Bitcoin. The results obtained in this study are that the Bitcoin market is not efficient because at that time the bitcoin market was still relatively new and was developing. Then the research conducted by Latif et. al (2017) entitled Testing the weak Form of Efficient Market in Cryptocurrency. The results of this study indicate that the Bitcoin and Litecoin markets are efficient in a weak form, which means the crypto market is feeding on new information. Furthermore, the research conducted by Chun Wei (2018) entitled liquidity and market efficiency in cryptocurrencies. is a continuation of research from Urquhart (2016). The result of this study is that there is a strong relationship between liquidity and volatility among cryptocurrencies as well as in a liquid market, it is known that the efficiency is stronger and the volatility is lower because trading is active and tends to arbitrage. Then the research conducted by Vidal and Ibañez (2018) entitled Semi-strong efficiency of Bitcoin. The results obtained from this study are that over time Bitcoin becomes more efficient along with the bankruptcy of the MT. Gox however bitcoin itself does not respond to monetary policy news because bitcoin is not controlled by a central bank. Last, research conducted by Nan and Kaizoji (2019) entitled Market efficiency of the bitcoin exchange rate: weak and semi-strong form test with the spot, future, and forward foreign exchange rates. The results of this study are the Bitcoin or spot exchange rate, futures and forwards have a process random walk or changes in current exchange rates are independent and the rate of change that occurs is in accordance with the weak form market efficiency. Based on this research the hypothesis in this study is:

HO : The Bitcoin market and the foreign exchange market are efficient in weak form against the Bitcoin exchange rate and the USD and IDR currencies.

H1 : The Bitcoin market and the foreign exchange market are efficient in semi-strong form against the Bitcoin exchange rate and the USD and IDR currencies 


\section{RESEARCH METHODOLOGY}

\section{A. Forward Exchange Rate}

The forward exchange rate is determined based on the spot exchange rate prevailing at the time of the transaction by considering the interest rate between the two currencies being transacted. The equation used to calculate the forward exchange rate is:

$$
\text { Forward }=(\text { spot })+(\mathrm{r} 1-\mathrm{r} 2) \times(\mathrm{n} / 360) \times(\mathrm{spot})
$$

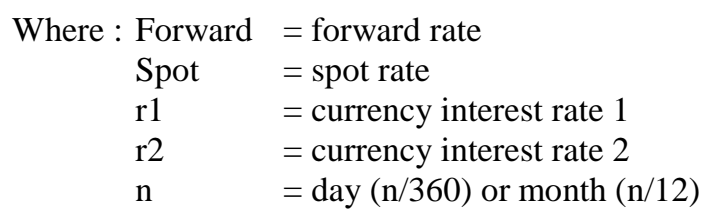

\section{B. Future Exchange Rate}

The Future exchange rate uses the Bitcoin spot exchange rate against USD and IDR as well as the USD and IDR exchange rate which is predicted using the Least Square Method. The equation used to calculate the future exchange rate is:

$$
Y^{\prime}=a+b(x)
$$

Where : $\mathrm{Y}^{\prime}=$ nilai tukar Future

$$
\begin{aligned}
& \mathrm{a}=(\Sigma \mathrm{Y}) / \mathrm{n} \\
& \mathrm{b}=(\Sigma \mathrm{XY}) /(\Sigma \mathrm{X})^{2}
\end{aligned}
$$

\section{Normality Test}

According to Ghozali (2018: 161) the normality test aims to find out whether data is normally distributed or not through the residual value. A data is said to be good if it has a residual value that is normally distributed. In this study, a normality test was carried out using the Jarque-Bera method. According to Winarno (2017: 540) Jarque-Bera is a statistical test used to find out whether data is normally distributed. The basis for decision making can be done by looking at the value of kurtosis and skewness, the equations used are:

$$
\text { Jarque }- \text { Bera }=\frac{N-k}{6} S^{2}+\left[\frac{(K-3)^{2}}{4}\right]
$$

Where: $\mathrm{S}$ = skewness

$\mathrm{K}=$ kurtosis

$\mathrm{k}=$ number of coefficients used

Decision making is done by making a basic hypothesis, namely:

H0 = data are normally distributed

H1 = data are not normally distributed

Based on the basic hypothesis that has been described, there are two choices for normality test decisions, namely:

1) If the jarque-fall value $<2$, then the data is normally distributed.

2) If the probability value is $>0.05$, the data is normally distributed.

\section{Stationery Test}

The stationarity test in this study used Augmented Dickey Fuller (ADF), Kwiatkowski-Phillips- SchmidtShin (KPSS), and Elliott-Rotenberg-Stock (ERS).

\section{a) Augmented Dickey Fuller (ADF)}

The hypothesis of this stationary test is:

$$
\begin{aligned}
& \text { H0 = data has a unit root (data is not stationary) } \\
& \text { H1 = data does not have a unit root (data is stationary) }
\end{aligned}
$$

Based on this hypothesis, the stationary test decision making with ADF is as follows:

1) If the t-statistic value < McKinnon's critical value $(1 \%, 5 \%, 10 \%)$, then $\mathrm{H} 0$ is accepted. 
2) If the t-statistic value > the critical value of McKinnon $(1 \%, 5 \%, 10 \%)$, then $\mathrm{H} 0$ is rejected.

\section{b) Kwiatkowski-Phillips-SchmidtShin (KPSS)}

The hypothesis of this stationary test is:

$\mathbf{H 0}=$ stationary data (data does not have a unit root)

H1 = data is not stationary (data has a unit root)

Based on this hypothesis, the decision making for the stationary test with KPSS is as follows:

1) If the t-statistic value < McKinnon's critical value $(1 \%, 5 \%, 10 \%)$, then $\mathrm{H} 0$ is accepted.

2) If the t-statistic value $>$ the critical value of McKinnon $(1 \%, 5 \%, 10 \%)$, then $\mathrm{H} 0$ is rejected.

\section{c) Elliott-Rothenberg-Stock (ERS)}

The hypothesis of this stationary test is:

H0 = data has a unit root (data is not stationary)

H1 = data does not have a unit root (data is stationary)

Based on this hypothesis, the decision making for the stationary test with KPSS is as follows:

1) If the t-statistic value <McKinnon's critical value $(1 \%, 5 \%, 10 \%)$, then $\mathrm{H} 0$ is accepted.

2) If the t-statistic value> the critical value of McKinnon $(1 \%, 5 \%, 10 \%)$, then $\mathrm{H} 0$ is rejected.

In this study, the Kwiatkowski-Phillips-SchmidtShin (KPSS) and Elliott-Rothenberg-Stock (ERS) test methods are only additional methods. In this study, a stationary test was used to test the efficiency of the bitcoin market and the weak foreign exchange market (Nan and Kaizoji, 2019).

\section{E. Optimal Lag}

Determination of the optimal lag in this study utilizes some information using Akaike Information Criterion (AIC), Schward-Bayes Criterion (SC), Hannan-Quinn (HQ), and Akaike's Final Prediction Error Criterion (FPE).

\section{F. Cointegration}

According to Basuki (2016: 253) the cointegration test was carried out to determine the long-term relationship between variables. If there is cointegration between the variables used, it can be concluded that there is a long-term relationship between variables. In this study, using the cointegration test with the Johansen Cointegration method. The hypothesis of the cointegration test is:

$\mathbf{H 0}=$ there is no cointegration between variable.

H1 $=$ there is cointegration between variable.

The criteria for decision making are:

1) If the trace statistic and maximum eigenvalues are at $\mathrm{r}=0>$ critical value $(1 \%, 5 \%)$, then $\mathrm{H} 0$ is rejected.

2) If the trace statistic value and maximum eigen at $\mathrm{r}=0<$ critical value $(1 \%, 5 \%)$, then $\mathrm{H} 0$ is accepted

\section{G. Model VECM}

VECM modeling is carried out to determine the short and long term relationship of each variable that has a cointegration relationship. Decision making based on the value of the t-statistic.

1) If $|t-s t a t i s t i c|>$ coefficient then there is a short-term relationship either positive or negative.

\section{RESULT AND DISCUSSION}

\section{A. Forward exchange Rate}

The following is an example of calculating forward exchange rates for one month, three months, six months, and twelve months:

- Spot exchange rate on September 1, 2017

- interest rate in 2017

$=13,343$ USD

- IDR interest rate in 2017

$$
\begin{aligned}
& =1.17 \% \\
& =5.81 \%
\end{aligned}
$$

Based on the equation, it is known that the forward exchange rate for 1, 3, 6, and 12 month is : 
- Forward Exchange for 1 month :

$$
\text { Forward } 1=(13,343)+(5.81 \%-1.17 \%) \times(1 / 12) \times(13,343)=13,394.59
$$

Based on the calculation, it is known that the forward exchange rate for 1 month is Rp13,394.39, which means it is higher than the spot rate

- Forward Exchange for 3 months

$$
\text { Forward3 }=(13,343)+(5.81 \%-1.17 \%) \times(3 / 12) \times(13,343)=13,494.78
$$

Based on the calculation, it is known that the forward exchange rate for 3 months is Rp13,494.78, which means it is higher than the spot rate

- Forward Exchange for 6 months

$$
\text { Forward6 }=(13,343)+(5.81 \%-1.17 \%) \times(6 / 12) \times(13,343)=13,669.24
$$

Based on the calculation, it is known that the forward exchange rate for 6 months is Rp13,669.24, which means it is higher than the spot rate

- Forward Exchange for 12 months

$$
\text { Forward12 }=(13,343)+(5.81 \%-1.17 \%) \times(12 / 12) \times(13,343)=14,080.87
$$

Based on the calculation, it is known that the forward exchange rate for 12 months is Rp14,080.87, which means it is higher than the spot rate

\section{B. Future Exchange Rate}

The future exchange rate in this study is predicted using the Least Square method. The following is an example of calculating future exchange rates is:

Table 1. Future exchange rate.

\begin{tabular}{cccccc}
\hline Periode & $\mathrm{SPt}(\mathrm{Y})$ & Forecast $(\mathrm{X})$ & $\mathrm{X}^{2}$ & $\mathrm{X}^{*} \mathrm{Y}$ & Future \\
\hline 01-Sep-17 & $13.343,00$ & -10 & 100 & -133430 & $13.236,34$ \\
04-Sep-17 & $13.342,50$ & -9 & 81 & -120083 & $13.243,46$ \\
05-Sep-17 & $13.337,50$ & -8 & 64 & -106700 & $13.250,58$ \\
06-Sep-17 & $13.337,50$ & -7 & 49 & $-93362,5$ & $13.257,70$ \\
07-Sep-17 & $13.306,50$ & -6 & 36 & -79839 & $13.264,82$ \\
08-Sep-17 & $13.204,00$ & -5 & 25 & -66020 & $13.271,94$ \\
11-Sep-17 & $13.162,50$ & -4 & 16 & -52650 & $13.279,06$ \\
12-Sep-17 & $13.195,00$ & -3 & 9 & -39585 & $13.286,19$ \\
13-Sep-17 & $13.202,50$ & -2 & 4 & -26405 & $13.293,31$ \\
14-Sep-17 & $13.249,50$ & -1 & 1 & $-13249,5$ & $13.300,43$ \\
15-Sep-17 & $13.240,00$ & 0 & 0 & 0 & $13.307,55$ \\
18-Sep-17 & $13.255,00$ & 1 & 1 & 13255 & $13.314,67$ \\
19-Sep-17 & $13.278,50$ & 2 & 4 & 26557 & $13.321,79$ \\
20-Sep-17 & $13.281,50$ & 3 & 16 & 39844,5 & $13.328,91$ \\
21-Sep-17 & $13.281,50$ & 4 & 53126 & $13.336,03$ \\
22-Sep-17 & $13.312,50$ & 5 & 25 & 66562,5 & $13.343,15$ \\
25-Sep-17 & $13.326,00$ & 6 & 36 & 79956 & $13.350,27$ \\
26-Sep-17 & $13.376,50$ & 7 & 49 & 93635,5 & $13.357,39$ \\
27-Sep-17 & $13.440,00$ & 8 & 64 & 107520 & $13.364,51$ \\
28-Sep-17 & $13.515,00$ & 9 & 81 & 121635 & $13.371,63$ \\
29-Sep-17 & $13.471,50$ & 10 & 100 & 134715 & $13.378,76$ \\
\hline Total & $279.458,50$ & & 570 & 5483 & \\
\hline
\end{tabular}

Based on the calculation results, it is known that the equation of the linear line is $\mathrm{Y}=13.307,55+7,121 \mathrm{X}$, by using this equation the future prediction for September 1 in 2017 is: $\mathrm{Y}=\mathrm{IDR} 13.307,55+7,121 \mathrm{X}$ (for the value of X 1 September 2017 is -10), so: Y = IDR 13,307.55 + 7.121(-10) = IDR 13,236.34 
C. Normality Test

Table 2. Normality Test.

\begin{tabular}{lll}
\hline & Jarque_Bera & Probability \\
\hline BX & 527,7368 & 0,000000 \\
BXs & 49,34268 & 0,000000 \\
SP & 12,54392 & 0,001889 \\
FU & 12,00189 & 0,002476 \\
FW1 & 14,12983 & 0,000855 \\
FW3 & 15,21002 & 0,000498 \\
FW6 & 14,98495 & 0,000557 \\
FW12 & 19,29469 & 0,000065 \\
\hline
\end{tabular}

Based on the results of the normality test, it is known that the eight data series are not normally distributed because the Jarque-Bera value is greater than 2 and the probability value is smaller than 0.05 . However, according to Supranto (2009: 211), the use of the OLS method in research will produce a best linear unbiased Estimator (BLUE) regardless of whether the residual value is normally distributed or not. Therefore, this explains that the OLS estimator tends to approach the normal distribution if the sample is bigger or sample approaches infinity. So that the data can still be used in this study.

\section{Stationery Test}

Table 3. Stationery Test.

\begin{tabular}{lcccccc}
\hline \multirow{2}{*}{ Variabel } & \multicolumn{2}{c}{ ADF } & \multicolumn{2}{c}{ KPSS } & \multicolumn{2}{c}{ ERS } \\
\cline { 2 - 6 } & Lag & t-statistic & Lag & t-statistic & Lag & t-statistic \\
\hline BX & 0 & $-6,271556^{* * *}$ & 17 & $0,375281 * *$ & 3 & $-1,734873^{* * *}$ \\
BXs & 4 & $-3,419443^{* * *}$ & 18 & $0,365972 * *$ & 3 & $-0,928241$ \\
SP & 1 & $-1,894744$ & 18 & 1,161835 & 1 & $-0,664972$ \\
FU & 0 & $-1,913031$ & 18 & 1,168060 & 0 & $-0,210594$ \\
FW1 & 1 & $-1,891230$ & 18 & 1,142632 & 1 & $-0,670118$ \\
FW3 & 1 & $-1,887970$ & 18 & 1,135993 & 1 & $-0,682572$ \\
FW6 & 1 & $-1,887293$ & 18 & 1,137393 & 1 & $-0,678895$ \\
FW12 & 1 & $-1,876161$ & 18 & 1,116994 & 1 & $-0,753576$ \\
\hline
\end{tabular}

Note: $* 0.01$ significant, $* * 0.05$ significant, $* * * 0.10$ significant

Based on the results of table 3 it can be concluded that the Bitcoin spot and future exchange rates are stationary at the level level. However, the USD / IDR spot, future and forward exchange rates are not stationary at this level. It can be concluded that the Bitcoin market is inefficient in weak form because it does not follow Fama's (1970) random walk and is inversely proportional to the USD / IDR foreign exchange market which shows not stationary level. So it can be said that the USD / IDR foreign exchange market is efficient in its weak form.

To continue research on market efficiency in semi-strong forms, stationary data is needed, therefore data needs to be differentiated once in testing stationarity. Following are the results of the data tested at degree one.

Table 4. Stationery Test degree one.

\begin{tabular}{lcccccc}
\hline \multirow{2}{*}{ Variabel } & \multicolumn{2}{c}{ ADF } & \multicolumn{2}{c}{ KPSS } & \multicolumn{2}{c}{ ERS } \\
\cline { 2 - 6 } & Lag & t-statistic & Lag & t-statistic & Lag & t-statistic \\
\hline$\Delta \mathrm{BX}$ & 2 & $-18,27809 * * *$ & 30 & $0,112390 * * *$ & 2 & $-3,514579 * * *$ \\
$\Delta \mathrm{BXs}$ & 2 & $-9,970967 * * *$ & 14 & $0,125613 * * *$ & 2 & $-9,972365 * * *$ \\
$\Delta \mathrm{SP}$ & 0 & $-21,20606 * * *$ & 7 & $0,248767 * * *$ & 0 & $-21,20861 * * *$ \\
$\Delta \mathrm{FU}$ & 0 & $-22,71049 * * *$ & 10 & $0,370587 * * *$ & 0 & $-22,21359 * * *$ \\
$\Delta \mathrm{FW} 1$ & 0 & $-21,19072 * * *$ & 7 & $0,249523 * * *$ & 0 & $-21,16409 * * *$ \\
$\Delta \mathrm{FW} 3$ & 0 & $-21,19015 * * *$ & 7 & $0,245870 * * *$ & 0 & $-21,16421 * * *$
\end{tabular}




\begin{tabular}{lllllll}
$\Delta \mathrm{FW6}$ & 0 & $-21,19433 * * *$ & 7 & $0,246746 * * *$ & 0 & $-21,19743 * * *$ \\
$\Delta \mathrm{FW} 12$ & 0 & $-21,17529 * * *$ & 7 & $0,222422 * * *$ & 0 & $-21,15452 * * *$ \\
\hline
\end{tabular}

Based on the results of table 4, data that has been differentiated once shows that all variables are stationary. So that it can be used to test long-term relationships using cointegration.

\section{E. Optimal Lag}

Determining the optimal lag is useful in producing efficient estimates. The determination of lag in this study uses the VAR model.

Table 5. Optimal Lag.

\begin{tabular}{lccccc}
\hline \multicolumn{1}{c}{ Series Pair } & Obvs. & AIC & SBC & HQ & FPE \\
\hline BX, SP & 608 & 2 & 1 & 1 & 2 \\
BXs, FU & 608 & 5 & 2 & 1 & 5 \\
BX, FW1 & 608 & 2 & 1 & 1 & 2 \\
BX, FW3 & 608 & 2 & 1 & 1 & 2 \\
BX, FW6 & 608 & 2 & 1 & 1 & 2 \\
BX, FW12 & 608 & 2 & 1 & 2 \\
\hline
\end{tabular}

Note: AIC (Akaike Information Criterion) SBC (Schward-Bayes Criterion) HQ (Hannan-Quinn), FPE (Akaike's Final Prediction Error Criterion)

Based on the results of table 5, it is known that the BX and SP pairs have an optimal lag of 2, the BXs and FU pairs have an optimal lag of 5, and the BX and FWt pairs have an optimal lag 2. From the lag results, a cointegration test is carried out to determine whether there will be a long-term balance.

\section{F. Cointegration}

Table 6. Cointegration.

\begin{tabular}{|c|c|c|c|c|c|}
\hline Series Pair & Lag & Eigenvalue & Hipotesis & Trace Statistic & Max-Eigen Statistic \\
\hline \multirow[t]{2}{*}{$\mathrm{BX}, \mathrm{SP}$} & 2 & 0,065385 & $r=0$ & $44,60478^{* *}$ & $40,91020 * *$ \\
\hline & & 0,006093 & $\mathrm{r} \leq 1$ & 3,697286 & 3,697286 \\
\hline \multirow[t]{2}{*}{$\mathrm{BXs}, \mathrm{FU}$} & 5 & 0,026400 & $\mathrm{r}=0$ & 19.30720 & $16,10642 * *$ \\
\hline & & 0,005303 & $r \leq 1$ & 3,200781 & 3,200781 \\
\hline \multirow[t]{2}{*}{ BX, FW1 } & 2 & 0,065487 & $\mathrm{r}=0$ & $44,65572 * *$ & $40,97648 * *$ \\
\hline & & 0,006063 & $\mathrm{r} \leq 1$ & 3,679245 & 3,679245 \\
\hline \multirow[t]{2}{*}{ BX, FW3 } & 2 & 0,065667 & $\mathrm{r}=0$ & $44,75471 * *$ & $41,09311 * *$ \\
\hline & & 0,006034 & $\mathrm{r} \leq 1$ & 3,661598 & 3,661598 \\
\hline \multirow[t]{2}{*}{ BX, FW6 } & 2 & 0,065641 & $\mathrm{r}=0$ & $44,73765 * *$ & $41,07678 * *$ \\
\hline & & 0,006033 & $\mathrm{r} \leq 1$ & 3,660875 & 3,660875 \\
\hline \multirow[t]{2}{*}{ BX, FW12 } & 2 & 0,066475 & $\mathrm{r}=0$ & $45,21226 * *$ & $41,61617 * *$ \\
\hline & & 0,005926 & $r \leq 1$ & 3,596091 & 3,596091 \\
\hline
\end{tabular}

Note: $* 0.01$ significant, $* * 0.05$ significant, $* * * 0.10$ significant

The test results from table 6 show that the value of trace statistic and maximum eigenvalue at $r=0$ is greater than the critical value with a significance level of $1 \%$ and $5 \%$ for the Bitcoin market pair and the spot, and forward forex market. This means that $\mathrm{HO}$ is rejected, so for the Bitcoin market pair and the spot foreign exchange market is also forward cointegrated. However, the results for the Bitcoin market pair and the foreign exchange futures market show that the result $\mathrm{H} 0: \mathrm{r}=0$ for the trace statistic is rejected and for the max-eigen it is accepted, this may interpret cointegration but in weak form.

\section{G. Model VECM}

Based on the results of table 6, it is known that five series pairs have cointegration, therefore these five series want to know the long and short term relationship through the VECM model. Based on the results of table 7 shows the results of the short-term relationship between Bitcoin and the spot and forward exchange rates have a negative effect on lag 2, this shows if the spot or forward USD / IDR increases 2 percent, then spot or forward Bitcoin will decrease in the short term by $7.6 \%$. The VECM estimate in the long term shows that the spot or forward USD / IDR has a negative effect on spot and forward Bitcoin with a coefficient of (-0.54) which means that if the spot or forward USD / IDR increases 1 percent, both spot and forward Bitcoin will decrease by $54 \%$. 
Based on the results of the VECM model which shows a negative effect, this means that $\mathrm{H} 2$ is rejected that the Bitcoin market and the efficient foreign exchange market are in a semi-strong form. The results of this test are in line with Fama's (1970) theory which states that if the market is inefficient in a weak form then the market will also be inefficient in a semi-strong form, there are also cases where bitcoin has not been legalized as an official currency in Indonesia.

Table 7. Model VECM.

\begin{tabular}{ccrrr}
\hline \multirow{2}{*}{ Series Pair } & \multicolumn{3}{c}{$\beta$} & \multicolumn{1}{c}{$\alpha$} \\
\cline { 2 - 4 } & $\beta 1$ & \multicolumn{1}{c}{$\beta 2$} & \multicolumn{1}{c}{$\beta 3$} & -0.547632 \\
BX, SP & 0.182158 & $-0.075680^{*}$ & 0.332123 & {$[-3.21784]$} \\
& {$[0.77203]$} & {$[-0.31846]$} & {$[1.41108]$} & -0.547682 \\
BX, FW1 & 0.178120 & $-0.074945^{*}$ & 0.328930 & {$[-3.23457]$} \\
& {$[0.75694]$} & {$[-0.31618]$} & {$[1.40123]$} & -0.546897 \\
BX, FW3 & 0.183136 & $-0.071595^{*}$ & 0.326386 & {$[-3.23838]$} \\
& {$[0.78364]$} & {$[-0.30418]$} & {$[1.40017]$} & -0.539026 \\
BX, FW6 & 0.177842 & $-0.071217^{*}$ & 0.324707 & {$[-3.23660]$} \\
& {$[0.77070]$} & {$[-0.30644]$} & {$[1.41072]$} & -0.539282 \\
BX, FW12 & 0.182158 & $-0.075680^{*}$ & 0.332123 & {$[-3.23801]$} \\
\hline
\end{tabular}

Note: $\beta=$ short-term relationship, $\alpha=$ long term relationship

\section{CONCLUSION}

Based on the research results it is known that the exchange rate of Bitcoin against USD and IDR is inefficient in the weak form as well as in the semi-strong form. This can be seen from the results of the unit root test which shows that the exchange rate is stationary so that it is not in accordance with Fama's (1970) theory that the data is in random walk. Also the results of the VECM model cointegration test which shows results that have a negative effect on the short and long term relationship between Bitcoin and USD / IDR. This is because bitcoin is not yet a legal currency in Indonesia so it does not reflect the available information in Indonesia.

Based on the research results, suggestions for investors and potential investors who want to invest in Bitcoin are expected to pay more attention to the value of Bitcoin in order to minimize the abnormal return rate. Due to the value of Bitcoin which fluctuates and is not affected by the information available. So it will make it difficult for investors to estimate the real value of Bitcoin. Suggestions for further research, in order to develop results research that has been conducted by researchers as well as using other currencies that are not involved in this study. In addition, it is hoped that further research will be carried out if Bitcoin transactions are legal as a medium of exchange in Indonesia due to the cointegration phenomenon that is formed between the Bitcoin exchange rate and the USD / IDR exchange rate.

\section{REFERENCES}

Basuki, A. (2016). Analisis Regresi Penelitian Ekonomi dan Bisnis : Dilengkapi Aplikasi SPSS dan Eviews, 1st ed., Jakarta, PT RajaGrafindo Persada.

Engle, R. F., dan Granger, C. (1987). Co-Integration and Error Correction: Representation, Estimation, and Testing. The Econometric Society, pp.251-276.

Fama, E. F. (1970). Efficient Capital Market: A Review of Theory and Empirical Work. Journal of Finance, pp.383-417.

Ghozali, H. (2018). Aplikasi Analisis Multivariate dengan program IBM SPSS 25, 9th ed., Semarang, Universitas Diponegoro.

Latif, Saiful R., Mohd, M., Amin, M., and Mohammad, A. (2017). Testing the Weak Form of Efficiency Market in Croptocurrency. Journal of Engineering and Applied Sciences, pp.2285-2288.

Nan, Z., dan Kaizoji, T. (2019). Market efficiency of the bitcoin echange rate: weak and semi-strong test with the spot, futures and forward foreign exchange rate. Internasional review of Financial Analysis, pp.273-281

Supranto J. (2008). Statistik: Teori dan Aplikasi, 7th ed., Jakarta, Erlangga. Urquhart, A. (2016). The 
Inefficiency of Bitcoin. Economics Letters, pp.1-7.

Vidal-Tomás, D., and Ibañes, A. (2018). Semi-Strong Efficiency of Bitcoin. Finance Research Letters, pp.259265.

Wei, W. C. (2018). Liquidity and Market Efficiency in Criptocurrencies. Economics Letters, pp.1-13. Wijaya, Firda N. (2019). Bitcoin Sebagai Digital Aset Pada Transaksi Elektronik Di Indonesia (Studi Pada PT.Indodax Nasional Indonesia). Jurnal Hukum Bisnis Bonum Commune, pp.126-136.

Winarno, Wing W. (2017). Analisis Ekonometrika dan Statistika dengan Eviews, Yogyakarta, STIM YKPN. 